\title{
RNA binding properties of the US11 protein from four primate simplexviruses
}

Sarah Tohme ${ }^{1,2}$, Cyprian D Cukier ${ }^{1,3}$ and Alberto Severini ${ }^{1,2^{*}}$

\begin{abstract}
Background: The protein encoded by the Us11 gene of herpes simplex viruses is a dsRNA binding protein which inhibits protein kinase R activity, thereby preventing the interferon-induced shut down of protein synthesis following viral infection. Us11 protein is not essential for infectivity in vitro and in mice in herpes simplex virus type 1 (HSV1), however this virus has a second, and apparently more important, inhibitor of PKR activity, the $\gamma_{1} 34.5$ protein. Recently sequenced simian simplexviruses SA8, HVP2 and B virus do not have an ORF corresponding to the $\gamma_{1} 34.5$ protein, yet they have similar, or greater, infectivity as HSV1 and HSV2.
\end{abstract}

Methods: We have expressed the US11 proteins of the simplexviruses HSV1, HSV2, HVP2 and B virus and measured their abilities to bind dsRNA, in order to investigate possible differences that could complement the absence of the $\gamma_{1} 34.5$ protein. We employed a filter binding technique that allows binding of the Us 11 protein under condition of excess dsRNA substrate and therefore a measurement of the true Kd value of Us11-dsRNA binding.

Results and Conclusions: The results show a Kd of binding in the range of $0.89 \mathrm{nM}$ to $1.82 \mathrm{nM}$, with no significant difference among the four Us11 proteins.

\section{Introduction}

The genus Simplexvirus comprises a number of closely related herpesviruses with very similar genetic structure and life cycles. Most simplexviruses, like the human simplex viruses types 1 and 2 (HSV 1 and HSV 2), B virus (Cercopithecine herpesvirus 1), SA8 (Cercopithecine herpesvirus 2) and herpes virus papio type 2 (Cercopithecine herpesvirus 16), infect primates and produce very similar oro-genital lesions in their natural hosts and may cause encephalitis or severe infections in mice and other hosts [1]. For example, B virus causes mostly orogenital lesions in macaques, but if transmitted to humans produces an often fatal ascending encephalomyelitis [1,2].

Complete sequencing of the genomes of simian simplexviruses have confirmed the close genetic homology [3-5]. All the genes are conserved and collinear, except for the $\gamma_{1} 34.5$ gene (RL1) which is present in HSV-1 and HSV-2, but absent from the simian simplexviruses $B$ virus, SA8 and HVP2.

\footnotetext{
* Correspondence: alberto.severini@phac-aspc.gc.ca

${ }^{1}$ National Microbiology Laboratory, Public Health Agency of Canada, 1015 Arlington Street, Winnipeg, MB, R3E 3R2, Canada

Full list of author information is available at the end of the article
}

The $\gamma_{1} 34.5$ protein is an important virulence factor in HSV-1. Null mutants for $\gamma_{1} 34.5$ loose their virulence in mice and they show a severely impaired replication in cells culture [6,7]. These mutants can be rescued by a compensatory mutation that puts the US11 ORF under the control of an immediate early promoter [8-10]. In fact, both $\gamma_{1} 34.5$ and US11 proteins act by inhibiting the activation of the interferon-dependent protein kinase $R$ (PKR) response. PKR is activated by binding to dsRNA and it phosphorylates the ribosomal translation factor eIF2 $\alpha$, thereby blocking cellular protein synthesis. $\gamma_{1} 34.5$ promotes de-phosphorylation of eIF $2 \alpha[7,11]$ while US11 inhibits PKR activation by binding to dsRNA $[11,12]$. Since simian simplexviruses lack the $\gamma_{1} 34.5$ gene and yet replicate very well in culture and may show neurovirulence in mice, it is tempting to speculate that US11 may take over the entire inhibition of the PKR system in these viruses.

US11 is a ribosome associated protein which is produced late in infection and is packaged into the viral tegument at approximately 1000 copies $[13,14]$. US11 is not thought to be necessary for early gene expression or DNA replication, however it has been found that HSV 1 
relies more heavily on US11 in later stages of its lifecycle to prevent an antiviral state [15-17].

US11 is thought to inhibit PKR via the sequestering of dsRNA [11]. US11 has also been shown to inhibit PKR activation by binding to PACT, an RNA-independent mechanism of activating PKR [18]. In addition, US11 has recently been shown to counteract OAS (2'-5' oligoadenylate synthetase), an interferon inducible gene also activated by dsRNA, in part by sequestering dsRNA through its C-terminal domain [19].

US11 binds dsRNA via a unique motif comprised of a set of R-X-P repeats at the C-terminal end of the gene. The R-X-P motifs bind to dsRNA with high affinity, with Kds reported in the range of 12 to $70 \mathrm{nM}[12,20]$. US11 bind to dsRNA of minimum length of $39 \mathrm{bp}$ and preferentially binds RNA structures of higher-order and greater sequence complexity $[12,20]$.

Within the simplexviruses that express US11, the protein is highly conserved except for the number of R-X-P at the C-terminal end of the protein. HSV 1 contains 20 to 24 copies of R-X-P repeats, the number of repeats has been shown to vary among viral strains but is not a strain specific feature. HSV2 contains 19-20 repeats and this also is thought to vary slightly among strains. Within the non-human primate viruses; B virus (strain E2490) contains 20 R-X-P repeats, SA8 strain B264 contains only 10 while HVP2 (strain X313) has 32 R-X-P repeats, although there is considerable variation in the number of repeats among HVP2 strains.

In this work we have expressed in E. coli US11 proteins from the human simplexvirus HSV-1, HSV-2, and the simian simplexviruses HVP-2 and B-virus and we investigated if there are differences in dsRNA binding activities that could indicate different roles of US11 in the two groups of simplexviruses.

\section{Materials and methods}

\section{Cell Culture and Viruses}

Vero cells (ATCC number CCL-81) were maintained in Dulbecco's modified Eagle's medium (DMEM) supplemented with $5 \%$ calf serum. HSV 1 (strain F), HSV 2 (strain G) were obtained from The American Tissue Culture Collection (ATCC numbers VR-733 and VR734, respectively). Herpes papio 2 (HVP2, strain X313), originally isolated in Dr. Richard Eberle's laboratory, University of Oklahoma, and B virus (strain E2490) were obtained from the Southwest Foundation for Biomedical Research, San Antonio, TX, USA. Simian agent 8 (SA8, strain B264) was donated by Dr. Heinz Feldman, National Microbiology Laboratory, Winnipeg Manitoba. Viral genomic DNA was prepared as previously described [4]. Genomic DNA from B virus was prepared in the biosafety level 4 facility at the National Microbiology Laboratory of the Public Health Agency of Canada.

\section{US11 Recombinant Protein Expression and Purification}

The US11 gene was amplified by polymerase chain reaction (PCR) using the following sets of primers: HSV1, forward 5'GGAATTCCATATGAGCCAGACCCAACC3' and reverse 5'CCCAAGCTTCTATACAGACCCGCGAG3'; HSV2, forward 5' GGAATTCCATATGGCAT CCGGGGTT3' and reverse 5'CCCAAGCTTCTAGGCAAGCCCGCG3'; B virus, forward 5'GGAATTCCATATGCTAATGGCGTCAA3' and reverse 5'CCCAAGC TTGAAACCTCATCAACCC3'; SA8, forward 5'GGAAT TCCATATGGCGTCCGCGCCC3' and reverse 5'CCC AAGCTTAGGGGGCCGTCCTCACC3'; and HVP2 forward 5'GGAATTCCATATGGCGTCCGTGGCC3' and reverse 5'CCCAAGCTTAGGGGGCCGTCCTCAC3'. The oligonucleotides were designed using the software VectorNTI (Invitrogen, CA, USA), on the basis of the following GenBank sequences: HSV 1 strain 17 (NC_001806), HSV2 strain HG52 (NC_001798), B virus strain E2490 (NC_004812), SA8 (NC_006560), HVP2 (NC_007653), and contained HindIII and NdeI restriction sites at the $3^{\prime}$ and 5 ' ends respectively, for cloning into the E. coli expression vector pET28a(+) (Novagen, CA, USA). The US11 clones, containing an amino terminal hexahistidine tag, were produced in BL21 (DE3) competent E. coli cells (Novagen, CA, USA) and sequenced for confirmation at the DNA Core Facility (National Microbiology Laboratory, Winnipeg).

For expression of the US11 proteins, E. coli clones were grown in $1 \mathrm{~L}$ of $\mathrm{LB}$ medium to an $\mathrm{OD}_{600}$ of about 0.6 in the presence of $50 \mu \mathrm{g} / \mathrm{ml}$ of kanamycin. US11 was induced by adding $1 \mathrm{mM}$ isopropyl- $\beta$-thiogalatopyranoside (IPTG, Novagen) and incubated at $25^{\circ} \mathrm{C}$. Cells were harvested by centrifugation at $10000 \mathrm{rpm}$ for $10 \mathrm{~min}-$ utes, resuspended in lysis buffer $(20 \mathrm{mM}$ Tris-HCL, 10 $\mathrm{mM}$ imidazole, $1 \%$ triton $\mathrm{x}-100,10 \mathrm{mM} \beta$-mercaptoethanol, $\mathrm{pH}$ 8.0) with the addition of a protease inhibitor cocktail (Sigma, ON, Canada) and sonicated 5 times for 20 second intervals. Soluble and insoluble fractions of protein were separated by centrifugation at $14000 \mathrm{rpm}$. Most of the US11 was found in the soluble fractions and these fractions were stored at $-20^{\circ} \mathrm{C}$ and used in the experiments described in this work.

\section{Purification of US11 Proteins}

US11 proteins expressed with a His tag were purified on a Ni affinity column, prepared by equilibrating $\mathrm{Ni}$ resin (Profinity ${ }^{\mathrm{TM}}$ IMAC Ni-charged resin, Biorad, USA) with $1 \mathrm{X}$ binding buffer (20 mM Tris-HCL pH 7.4, $10 \mathrm{mM}$ imidazole, $1 \mathrm{M} \mathrm{NaCl}, 1 \%$ triton $\mathrm{x}-100,10 \mathrm{mM} \beta$-mercaptoethanol). E. coli extracts were mixed with an equal volume of $2 \mathrm{X}$ binding buffer (20 mM Tris-HCL pH 7.4, $10 \mathrm{mM}$ imidazole, $2 \mathrm{M} \mathrm{NaCl}, 1 \%$ triton $\mathrm{x}-100,10 \mathrm{mM}$ $\beta$-mercaptoethanol) and applied to the affinity column. The addition of $1 \mathrm{M} \mathrm{NaCl}$ in the binding buffer was 
necessary to dissociate RNA that was bound to the US11 protein after lysis. The Ni column was washed with 10 bed volumes of wash buffer 1 ( $20 \mathrm{mM}$ TrisHCL, $10 \mathrm{mM}$ imidazole, $1 \mathrm{M} \mathrm{NaCl}, 1 \%$ triton $\mathrm{x}-100,10$ $\mathrm{mM} \beta$-mercaptoethanol $\mathrm{pH} 7.4$ ) and then wash buffer 2 (20 mM Tris-HCL pH 7.4, $10 \mathrm{mM}$ imidazole, $300 \mathrm{mM}$ $\mathrm{NaCl}, 1 \%$ triton $\mathrm{x}-100,10 \mathrm{mM} \beta$-mercaptoethanol). US11 was eluted with elution buffer $(20 \mathrm{mM}$ Tris-HCL $\mathrm{pH}$ 7.4, $300 \mathrm{mM}$ imidazole, $300 \mathrm{mM} \mathrm{NaCl}, 1 \%$ triton $\mathrm{x}$ 100, $10 \mathrm{mM} \beta$-mercaptoethanol).

$\mathrm{Ni}$ column fractions containing US11 protein were pooled and loaded onto a $1 \mathrm{ml}$ HiTrap heparin HP column (GE Healthcare) apparatus an AKTA FPLC system (GE Healthcare, QC, Canada), using phosphate buffer $\left(10 \mathrm{mM} \mathrm{NaPO}_{4} \mathrm{pH}\right.$ 7.4). The US11 protein was eluted with a gradient of $\mathrm{NaCl}$ in phosphate buffer from 0 to $1.5 \mathrm{M}$, at a flow rate of $1 \mathrm{ml} / \mathrm{min}$. Fractions containing US11 were confirmed by SDS-PAGE on a $15 \%$ SDSPAGE gel and the protein concentration was measured using the RcDc Protein Assay kit (Biorad). The identity of US11 was confirmed by western blot analysis with an anti-polyhistidine mouse monoclonal antibody (Sigma), and by mass spectrometry at the Proteomics Core facility of the National Microbiology Laboratory, Winnipeg, Manitoba.

\section{Electrophoretic Mobility Shift Assays (EMSAs)}

The RNA used for detecting protein binding was a randomly designed $42 \mathrm{bp}$ double stranded synthetic fragment of sequence 5'UUCUCAAGUGAAGUCUGC UGAAGUACGUAACCUUAGAUACAU3' (Invitrogen). A dsDNA fragment of corresponding sequence was used as a binding control. Binding reactions were prepared using varying concentration of purified US11 protein (4 $\mathrm{ng}-366 \mathrm{ng})$ and $20 \mathrm{ng}$ of dsRNA in binding buffer (150 $\mathrm{mM} \mathrm{KCl}, 0.1 \mathrm{mM}$ DTT, $0.1 \mathrm{mM}$ EDTA and $50 \mathrm{mM}$ Tris, $\mathrm{pH}$ 7.4) in a final reaction volume of $20 \mu \mathrm{l}$. US11 and dsRNA were allowed to bind at room temperature for 30 minutes without agitation. An aliquot of gel loading buffer $(0.25 \%$ bromophenol blue, $0.25 \%$ xylene cyanol, $15 \%$ ficoll-type 400 ) was added to the reaction mixtures and resolved on $10 \%$ non-denaturing polyacrylamide gels in $1 \mathrm{X} \mathrm{TBE}$.

\section{Filter Binding Assays}

US11/dsRNA binding reaction was performed in $2 \mathrm{ml}$ of binding buffer $(150 \mathrm{mM} \mathrm{KCl}, 0.1 \mathrm{mM}$ DTT, $0.1 \mathrm{mM}$ EDTA and $50 \mathrm{mM}$ Tris, pH 7.4) containing $5 \% \mathrm{Ni}$ resin, a fixed amount of purified US11 protein and variable concentrations of ${ }^{32} \mathrm{P}$ labeled dsRNA, obtained by serially diluting a solution of $31 \mathrm{nM}$ of dsRNA trace-labeled with about $2 \times 10^{6} \mathrm{cpm}$ of end-labeled RNA. With this procedure all the dilutions of dsRNA had the same specific activity. The tubes were incubated for 25 minutes at room temperature with gentle mixing and then loaded onto Whatman GF/C filters on a vacuum manifold (VWR). The reactions were filtered immediately and the filters were washed 3 times with $10 \mathrm{~mL}$ of ice cold $1 \mathrm{X}$ binding buffer. The radioactivity bound to the filter was counted using a LS 6500 scintillation counter.

Background radioactivity bound to the filter was determined by running in parallel for each dsRNA concentration controls containing all the reagents except for the US11 protein.

\section{Determining Kd Values and Statistical Analysis}

A specific activity for each experiment was calculated as the average $\mathrm{cpm} / \mathrm{nmoles}$ for each dsRNA concentration. The pmoles of dsRNA bound to the filter for each dsRNA concentration was calculated as:

$$
\text { pmoles }=\frac{\mathrm{cpm} \text { in sample }-\mathrm{cpm} \text { blank }}{\text { specific activity }}
$$

The dissociation constant $(\mathrm{Kd})$ and the total amount of binding sites $[\mathrm{P}]$ was calculated by non-linear regression of the equilibrium binding equation:

$$
[\mathrm{P} \cdot \mathrm{RNA}]=[\mathrm{P}][\mathrm{RNA}] /(\mathrm{Kd}+[\mathrm{RNA}])
$$

Where: [P.RNA] is the amount of protein and RNA complexes as calculated from the binding experiments and [RNA] is the concentration of dsRNA in each point. The software also estimated the standard error of the calculated $\mathrm{Kd}$ and [P].

Several experiments were performed to determine the $\mathrm{Kd}$ of each US11 protein. A weighted average of the Kd values and standard deviation of the weighted average was calculated according to the formulas from Bevington and Robinson [21]. A one-way ANOVA test was performed to establish whether the Kd values were significantly different. GraphPad Prism ${ }^{\circledR}$ software was used for these analyses.

\section{Results}

\section{Protein expression and RNA binding activity}

RNA-binding activity of the expressed and purified US11 proteins was assessed by electrophoretic mobility shift assay (EMSA). Figure 1A shows the binding activity of US11 from HSV 1 to the 42 base pair random sequence of RNA, as described in Materials and Methods. We chose the length of 42 base pairs based on previous work which showed that US11 from HSV1 binds a minimum of 39 to a maximum of $300 \mathrm{bp}$ of dsRNA efficiently [12].

At lower concentrations of protein (lanes 4-7; $4.3 \mathrm{ng}$, 6.4 ng, $9.7 \mathrm{ng}$ and $14.5 \mathrm{ng}$ US11) only one shifted band is visible by ethidium bromide staining. A second band of higher molecular weight (MW) appears at higher 


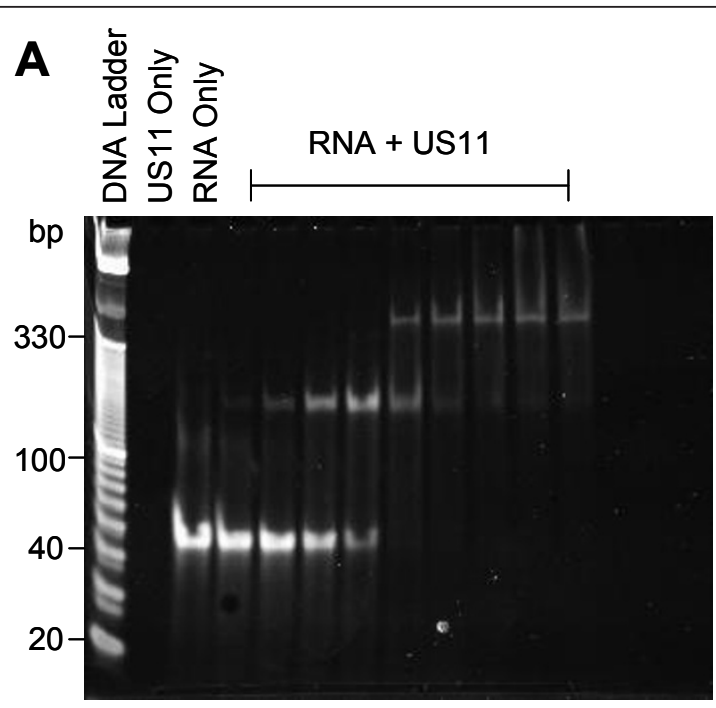

$\begin{array}{llllllllllll}1 & 2 & 3 & 4 & 5 & 6 & 7 & 8 & 9 & 10 & 11 & 12\end{array}$

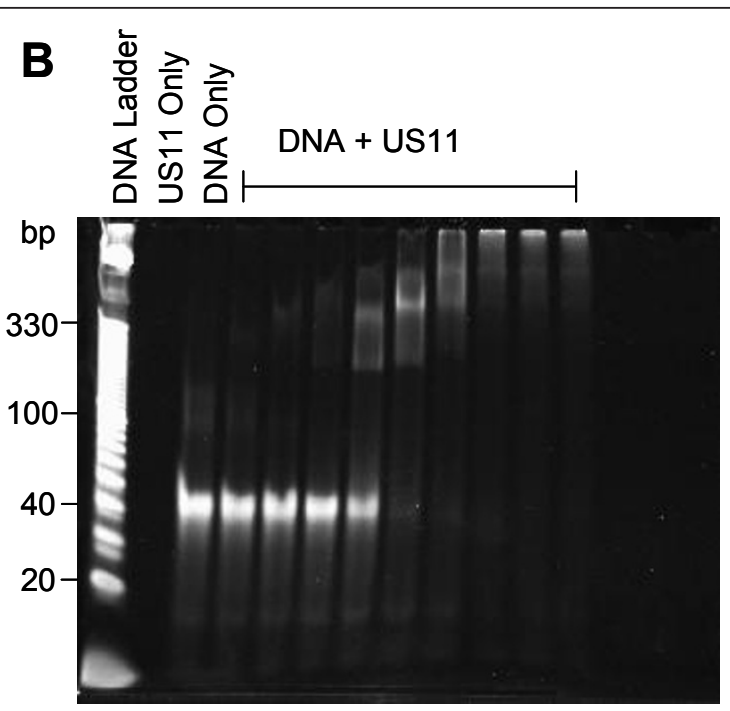

$\begin{array}{llllllllllll}12 & 3 & 4 & 5 & 6 & 7 & 8 & 9 & 10 & 11 & 12\end{array}$

Figure 1 EMSA of US11 protein from HSV1, to demonstrate its ability to bind to nucleic acids. Increasing concentration of US11 protein ranging from 4.3-112 ng (from lane 4 to 12, respectively) were incubated with $20 \mathrm{ng}$ of nucleic acid substrate and then run on a 10\% acrylamide gel and stained with ethidium bromide. A) A 42 bp dsRNA was used as substrate. B) A 42 bp dsDNA with sequence corresponding to the dsRNA was used as substrate.

concentrations of protein (lanes 8-10; $21.8 \mathrm{ng}, 32.6 \mathrm{ng}$ and $49.0 \mathrm{ng}$ US11) and some RNA forms a high MW smear or remains trapped in the gel wells at the highest protein concentration (lanes 11-12; 73.5 and $110 \mathrm{ng}$ US11). This result indicates that more than one molecule of US11 protein can bind to one molecule of dsRNA. All US11 proteins from HSV 1, HSV 2, B virus and HVP2 remained active post-purification as they all bound dsRNA with similar kinetics (Figure 2). US11 from SA8 did not express in the E. coli system and therefore US11 from SA8 was not used in the rest of the study.

US11 has been described predominantly as an RNA binding protein, although some previous reports in the literature show that US11 is also able to bind dsDNA $[14,15]$. Figure $1 B$ shows that US11 does bind dsDNA but with a lower affinity and not in a discernable stoichiometric manner. The dsDNA substrate used for this experiment had a nucleotide sequence corresponding to the sequence of the dsRNA substrate.

\section{Determination of Kd for US11 proteins from HSV1, HSV2, $B$ virus and HVP2}

In order to determine the Kd of US11 proteins for dsRNA we used the filter binding assay described in detail in Materials and Methods. For this assay the purified His tagged US11 proteins are bound to Ni resin and, after incubation with 32P-labelled RNA substrate, the free radioactivity is removed by filtration. This classic binding method has the advantage over EMSA of the possibility of measuring the real equilibrium binding, by using excess amounts of RNA substrate and rapidity of washing, as opposed to the small sample volume for electrophoresis and the many hours of an electrophoresis run, during which a substantial portion of RNA bound protein may dissociate. In addition, filter binding is more quantitative than measuring radioactivity on $\mathrm{X}$ ray image or a cut gel slice.

In order to confirm that the filter binding method was free of artifacts that could influence the calculation of $\mathrm{Kd}$, we performed two binding kinetic experiment, using a fixed concentration of RNA and varying concentrations of Us11 (Figure 3A), or using varying concentrations of RNA and a fixed concentration of Us11 protein from HSV1 (Figure 3B). The calculated Kd were $0.65 \pm$ $0.14 \mathrm{nM}$ and $0.70 \pm 0.09 \mathrm{nM}$, and they were not significantly different as determined by an unpaired $t$-test ( $p$ value $=0.7)$, indicating that the true $K d$ value was determined.

In order to accurately measure and compare the $\mathrm{Kd}$ of the US11 proteins from HSV1, HSV2, HVP2 and B virus, we performed filter binding assays over a range of dsRNA concentrations of $31 \mathrm{nM}-200 \mathrm{nM}$ in parallel for the four viruses.

Table 1 shows the results of 5 independent binding experiments. For each experiment the $\mathrm{Kd}$ was calculated by non-linear regression of the binding equation described in Materials and Methods (as done for example in Figure 3A) and the standard errors were also estimated. The last line of table 1 reports the weighted 


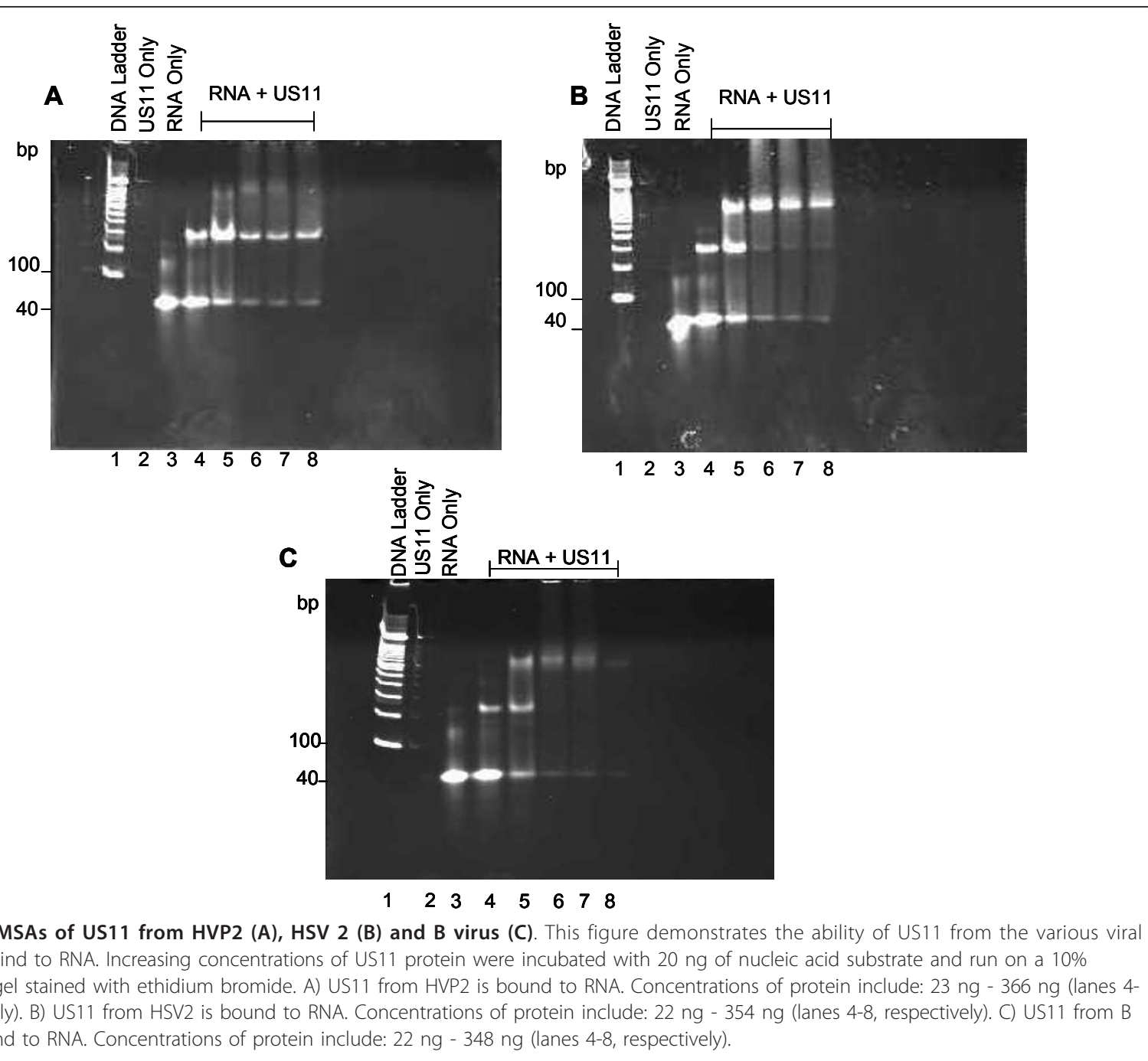

mean of the Kd for each US11 protein and the weighted standard deviation. The standard error of the Kd calculated by the non-linear regression was used as weight. None of the differences between Kd values for different US11 proteins were statistically significant, as determined by a one-way ANOVA test.

There was some variation in the $\mathrm{Kd}$ determinations among different experiments, but, except for experiment 3 , Kds for different viruses were not significantly different also within each experiment (Table 1, rightmost column).

\section{Discussion}

US11 inhibits interferon-mediated shutoff of protein synthesis by the PKR system, but its exact role during the course of herpesvirus infection still remains unclear. US11 is not essential for HSV replication in culture [22], but HSV also produces a second protein that inhibits PKR, $\gamma_{1} 34.5$, which is in turn essential for infectivity in cells and mice. In contrast, simian simplexviruses lack a $\gamma_{1} 34.5$ gene and US11 seems to be the only protein with PKR inhibitory activity. In order to investigate possible differences in activity between

Table 1 Determination of the Kd of binding to dsRNA of US11 proteins from four simplexviruses.

\begin{tabular}{cccccc}
\hline Experiment & HSV1 & HSV2 & B virus & HVP2 & p \\
\hline $1^{\text {a }}$ & $0.46 \pm 0.40$ & $0.29 \pm 0.14$ & $0.35 \pm 0.28$ & $0.42 \pm 0.31$ & 0.978 \\
$2^{a}$ & $2.34 \pm 0.95$ & $0.30 \pm 0.52$ & $6.07 \pm 1.40$ & $6.28 \pm 3.09$ & 0.068 \\
$3^{a}$ & $2.60 \pm 1.13$ & $1.14 \pm 0.29$ & $4.36 \pm 1.35$ & $6.10 \pm 1.58$ & 0.039 \\
$4^{a}$ & $1.84 \pm 0.37$ & $1.38 \pm 0.15$ & $1.69 \pm 2.35$ & $1.13 \pm 0.27$ & 0.975 \\
$5^{a}$ & $1.25 \pm 0.26$ & $1.66 \pm 0.60$ & $2.23 \pm 0.94$ & $2.58 \pm 0.28$ & 0.408 \\
\hline w. mean $^{\mathrm{b}}$ & $1.43 \pm 0.29$ & $0.89 \pm 0.42$ & $1.82 \pm 3.42$ & $1.80 \pm 3.43$ & 0.92
\end{tabular}

${ }^{a} \mathrm{Kd}$ calculated by non-linear regression \pm estimated standard errors

${ }^{\mathrm{b}}$ weighted average calculated using $\mathrm{Kd}$ standard errors as weights \pm weighted standard deviation 


\section{A \\ Varying Concentration of HSV1 US11 Protein and a Fixed Concentration of RNA}

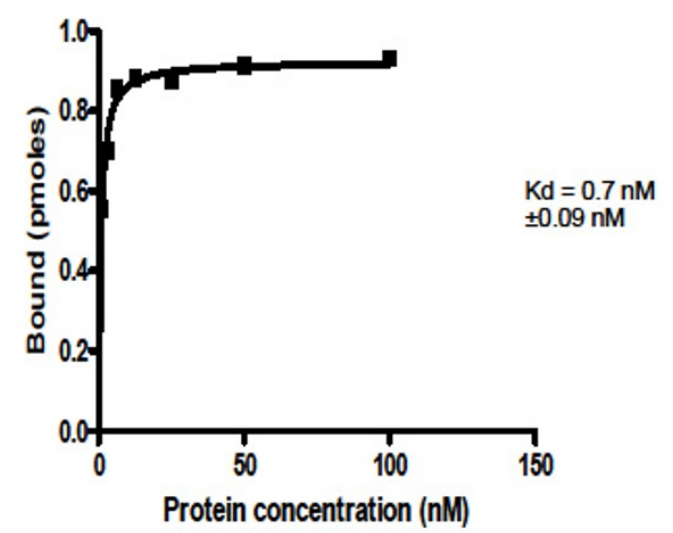

B

\section{Varying Concentration of RNA and a Fixed Concentration of HSV1 US11 Protein}

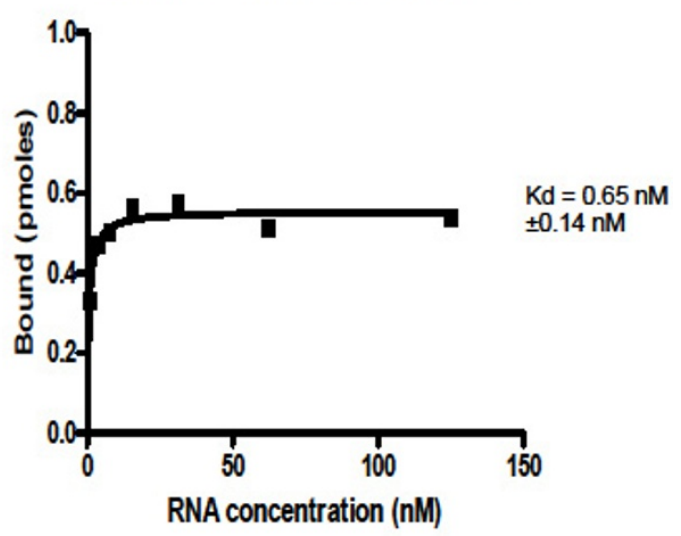

Figure 3 Determination of Kd of binding to dsRNA of US11 protein from HSV-1. The Kd was calculated by non-linear regression as described in Materials and methods and it is reported on the figure together with the estimated standard error. A) The Kd was determined with a fixed concentration of dsRNA (1 nM) and a range of concentration of proteins from 1 to $100 \mathrm{nM}$. B) The Kd was determined with a fixed concentration of protein $(2 \mathrm{nM})$ and a range of concentrations of dsRNA from 0.97 to $125 \mathrm{nM}$.

human and simian simplexviruses, we have studied the dsRNA binding activity of US11 expressed from HSV-1, HSV-2, HVP-2 and B virus.

Our results show that US11 proteins from HSV-1, HSV-2, HVP-2 and B virus bind the dsRNA substrate with the same affinity. In particular, there was no difference in Kd for US11 of HVP-2, despite the fact that this protein has a higher number of dsRNA-binding repeats. We determined the average $\mathrm{Kd}$ value for a synthetic dsRNA substrate at $1.07 \pm 1.86 \mathrm{nM}$. Previous studies $[12,20]$ have reported Kd values for US11 for different dsRNA species and showed that the affinity for dsRNA varied and was impacted by the length of the nucleic acid. Bryant et al. reports a $\mathrm{Kd}$ of $70 \mathrm{nM}$ in the case of US11 for a 67 bp dsRNA fragment which was achieved by electrophoretic mobility-shift assays. They were also able to map the binding site within a 46 base pair segment of the RNA. On the other hand Khoo et al. reported an apparent $\mathrm{Kd}$ value of $12.6 \mathrm{nM}$ for a $81 \mathrm{bp}$ dsRNA species using a filter binding assay [12]. The Kd values obtained thus far for US11 from HSV1 may be dependent on the size of the dsRNA fragment and probably also on the techniques used to establish the $\mathrm{Kd}$ value.

Our Kd is considerably lower of the range reported in the literature, but the method we used is more accurate than gel retardation technique used in the previous literature. Filter binding technique allows to work at equilibrium binding and in the presence of excess ligand. Binding experiments under conditions of excess of dsRNA or excess of US11 produced similar Kd values (Figure 3), indicating that the filter binding assays truly measures equilibrium binding.
In conclusion, there is no difference in dsRNA binding activity among the US11 proteins of these four simplexviruses, also despite the higher number of repeats of the R-X-P RNA binding motif. However, Us11 may bind RNA as a means of homing to PKR and physically inhibit the enzyme, and studies have shown that US11 forms a physical association with PKR [23]. It is also clear that US11 inhibits PKR $[11,15,16]$. Therefore it is possible that difference in expression kinetics of Us11 or differences in the interaction of Us11 with PKR may account for the ability of simian simplexviruses to function without expressing the $\gamma_{1} 34.5$ protein. Future research should compare the effect of Us11 from different simplexvirusees on the phosphorylation levels of PKR or eIF2 $\alpha$, in vitro or in cells infected by human or simian simplexviruses.

\section{Acknowledgements}

We would like to thank Keding Cheng and Dr. Garret Westmacott in the Proteomics and Mass Spectrometry Facility, Public Health Agency of Canada for the protein identification work.

\section{Author details}

${ }^{1}$ National Microbiology Laboratory, Public Health Agency of Canada, 1015 Arlington Street, Winnipeg, MB, R3E 3R2, Canada. ${ }^{2}$ Dept. of Medical Microbiology and Infectious Diseases, University of Manitoba, 745 Bannatyne Avenue, Winnipeg, Manitoba R3E 0J9, Canada. ${ }^{3}$ Department of Medical Biochemistry and Biophysics, Karolinska Institutet, SE-171 77 Stockholm, Sweden.

\section{Authors' contributions}

ST expressed and purified the US11 proteins, performed the binding experiments and analyzed the results. CDC developed the methodology for cloning and purification of the US11 proteins. AS designed and supervised this project and contributed to the analysis of the data. All authors contributed in the writing and final approval of this manuscript. 


\section{Competing interests}

The authors declare that they have no competing interests.

Received: 21 April 2011 Accepted: 3 November 2011

Published: 3 November 2011

\section{References}

1. Rogers KM, Ealey KA, Ritchey JW, Black DH, Eberle R: Pathogenicity of different baboon herpesvirus papio 2 isolates is characterized by either extreme neurovirulence or complete apathogenicity. J Virol 2003, 77:10731-10739.

2. Ritchey JW, Ealey KA, Payton ME, Eberle R: Comparative pathology of infections with baboon and African green monkey alpha-herpesviruses in mice. J Comp Pathol 2002, 127:150-161.

3. Perelygina L, Zhu L, Zurkuhlen H, Mills R, Borodovsky M, Hilliard JK: Complete Sequence and Comparative Analysis of the Genome of Herpes B Virus (Cercopithecine Herpesvirus 1) from a Rhesus Monkey. J Virol 2003, 77:6167-6177.

4. Tyler SD, Peters GA, Severini A: Complete genome sequence of cercopithecine herpesvirus 2 (SA8) and comparison with other simplexviruses. Virology 2005, 331:429-440.

5. Tyler SD, Severini A: The complete genome sequence of herpesvirus papio 2 (Cercopithecine herpesvirus 16) shows evidence of recombination events among various progenitor herpesviruses. J Virol 2006, 80:1214-1221.

6. Pasieka TJ, Baas T, Carter VS, Proll SC, Katze MG, Leib DA: Functional Genomic Analysis of Herpes Simplex Virus Type 1 Counteraction of the Host Innate Response. J Virol 2006, 80:7600-7612.

7. Chou J, Roizman B: The gamma 1(34.5) gene of herpes simplex virus 1 precludes neuroblastoma cells from triggering total shutoff of protein synthesis characteristic of programed cell death in neuronal cells. Proc Natl Acad Sci USA 1992, 89:3266-3270.

8. Cassady KA, Gross M, Roizman B: The herpes simplex virus US11 protein effectively compensates for the gamma1(34.5) gene if present before activation of protein kinase $\mathrm{R}$ by precluding its phosphorylation and that of the alpha subunit of eukaryotic translation initiation factor 2. J Virol 1998, 72:8620-8626.

9. Mohr I, Gluzman Y: A herpesvirus genetic element which affects translation in the absence of the viral GADD34 function. EMBO J 1996, 15:4759-4766

10. Mulvey M, Poppers J, Ladd A, Mohr I: A herpesvirus ribosome-associated, RNA-binding protein confers a growth advantage upon mutants deficient in a GADD34-related function. J Virol 1999, 73:3375-3385.

11. Poppers J, Mulvey M, Khoo D, Mohr I: Inhibition of PKR activation by the proline-rich RNA binding domain of the herpes simplex virus type 1 Us11 protein. J Virol 2000, 74:11215-11221.

12. Khoo D, Perez C, Mohr I: Characterization of RNA determinants recognized by the arginine- and proline-rich region of Us 11 , a herpes simplex virus type 1-encoded double-stranded RNA binding protein that prevents PKR activation. J Virol 2002, 76:11971-11981.

13. Benboudjema L, Mulvey M, Gao Y, Pimplikar SW, Mohr I: Association of the herpes simplex virus type 1 Us 11 gene product with the cellular kinesin light-chain-related protein PAT1 results in the redistribution of both polypeptides. J Virol 2003, 77:9192-9203.

14. Roller RJ, Monk LL, Stuart D, Roizman B: Structure and function in the herpes simplex virus 1 RNA-binding protein U(s)11: mapping of the domain required for ribosomal and nucleolar association and RNA binding in vitro. J Virol 1996, 70:2842-2851.

15. MacLean CA, Rixon FJ, Marsden HS: The products of gene US11 of herpes simplex virus type 1 are DNA-binding and localize to the nucleoli of infected cells. J Gen Virol 1987, 68:1921-1937.

16. Mulvey M, Camarena V, Mohr I: Full resistance of herpes simplex virus type 1-infected primary human cells to alpha interferon requires both the Us11 and gamma(1)34.5 gene products. J Virol 2004, 78:10193-10196.

17. Mulvey M, Poppers J, Sternberg D, Mohr I: Regulation of elF2alpha phosphorylation by different functions that act during discrete phases in the herpes simplex virus type 1 life cycle. J Virol 2003, 77:10917-10928.

18. Peters GA, Khoo D, Mohr I, Sen GC: Inhibition of PACT-mediated activation of PKR by the herpes simplex virus type 1 Us 11 protein. J Virol 2002, 76:11054-11064.
19. Sanchez R, Mohr I: Inhibition of cellular 2'-5' oligoadenylate synthetase by the herpes simplex virus type 1 Us 11 protein. J Virol 2007, 81:3455-3464.

20. Bryant KF, Cox JC, Wang H, Hogle JM, Ellington AD, Coen DM: Binding of herpes simplex virus-1 US11 to specific RNA sequences. Nucleic Acids Res 2005, 33:6090-6100.

21. Bevington PR, Robinson DK: Data Reduction and Error Analysis for the Physical Sciences. McGraw-Hill, New York; 2003.

22. Brown SM, Harland J: Three mutants of herpes simplex virus type 2: one lacking the genes US10, US11 and US12 and two in which Rs has been extended by $6 \mathrm{~kb}$ to 0.91 map units with loss of Us sequences between 0.94 and the Us/TRs junction. J Gen Virol 1987, 68:1-18.

23. Cassady KA, Gross M: The herpes simplex virus type $1 \mathrm{U}(\mathrm{S}) 11$ protein interacts with protein kinase $R$ in infected cells and requires a 30-aminoacid sequence adjacent to a kinase substrate domain. J Virol 2002, 76:2029-2035.

doi:10.1186/1743-422X-8-504

Cite this article as: Tohme et al:: RNA binding properties of the US11 protein from four primate simplexviruses. Virology Journal 2011 8:504.

\section{Submit your next manuscript to BioMed Central and take full advantage of:}

- Convenient online submission

- Thorough peer review

- No space constraints or color figure charges

- Immediate publication on acceptance

- Inclusion in PubMed, CAS, Scopus and Google Scholar

- Research which is freely available for redistribution 